UNDERGRADUATE RESEARCH IN NATURAL AND CLINICAL SCIENCE AND TECHNOLOGY (URNCST) JOURNAL Read more URNCST Journal articles and submit your own today at: https://www.urncst.com

\title{
Cellulose in Nature - Versatile Sources for Novel Applications: A Literature Review
}

\author{
Dusan B. Pesic, BSc Student [1]* \\ [1] Faculty of Science, McGill University, Montreal, Quebec, H3A 0G4 \\ *Corresponding Author: dusan.pesic@mail.mcgill.ca
}

\begin{abstract}
Introduction: Cellulose is the most abundant organic compound and the main component of the plant cell wall. However, it can be derived from other sources: tunicates, algae, and bacteria. Different sources of cellulose were shown to produce end-products of different mechanical properties and were considered for producing cellulose in non-industrial conditions.

Methods: Procedures for the extraction of cellulose from different sources are described. They are similar for plants and algae, including bleaching and purification processes amongst others, while bacteria found in symbiotic cultures of bacteria and yeasts (SCOBYs) are capable of growing cellulose layers above their cultivation media. After extraction or bacterial cultivation, mechanical treatments are performed in order to modify new cellulose layers for specific applications.

Results: Plant sources of cellulose are various and widely available, and often used for the industrial production of cellulose. Algae-derived microcrystalline cellulose (MCC) is similar to that from plant sources, but has higher crystallinity and, often, requires simpler extraction processes. Finally, cellulose grown by bacteria found in SCOBYs is the most optimal for non-industrial conditions, owing to the simplest cultivation and extraction procedures.

Discussion: On a large scale, plant sources of cellulose are the optimal ones. The main downside of algal cellulose is that it is season-dependent, and more difficult to acquire than bacterial and plant sources. While having access to laboratory conditions for incubations and using a pure bacterial culture would be preferable, cultivation methods are simple enough to be adapted for home conditions. Also, conditions of incubation can be varied based upon the intended properties of the endproduct: the efficiency of cellulose growth and its properties depend on the chosen carbon source. When bacteria produce a cellulose layer or it is extracted from another source, mechanical treatments for tuning porosity and other properties are applied. Conclusion: Sources of cellulose are numerous, and some are more suitable than others for non-industrial production, namely, using easily obtainable SCOBYs. This allows for a wide variety of applications: from artificial skin and face masks, to sustainable batteries and different food products.
\end{abstract}

Keywords: cellulose; tunable porosity; bottom-up synthesis; SCOBY; crystallinity

\section{Introduction}

Cellulose, being the main component of the plant cell wall, is a tough and water-insoluble polymer, which is one of the most abundantly found organic compounds. [1]. D-glucopyranose molecules linked by 1-4 glycosidic bonds (Figure 1) form chains that can either be arranged as fibrils or exhibit an amorphous structure. Between 40 and $45 \%$ of natural cellulose regions exhibit a higher degree of order, forming microcrystalline cellulose (MCC), while 55 to $60 \%$ of natural cellulose is amorphous [2]. Both growth and posttreatment conditions, along with the extraction process, affect the degree of crystallinity (DC), and therefore the derived material's properties such as strength and hydrophilicity. MCC is expected to have different chemical resistance compared to amorphous regions due to its ordered structure which inhibits penetration of chemicals [3]. MCC serves as a desirable filler which can be used for enhanced mechanical properties of silicones amongst other applications.

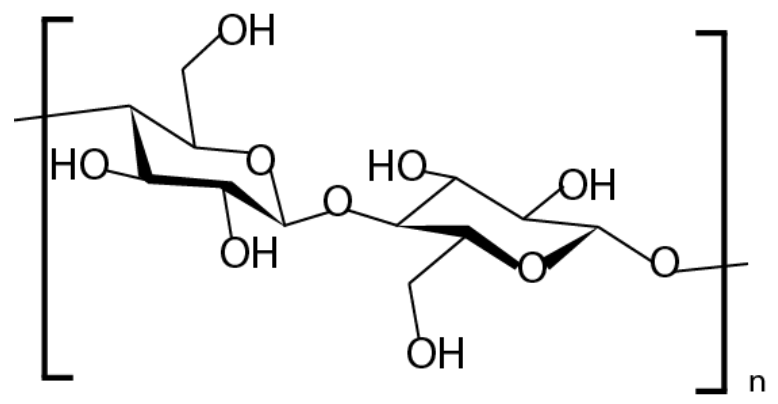

Figure 1. Chemical structure of the repeating unit of cellulose.

Types of Cellulose and Characteristics

Cellulose is found as one of four polymorphs: I, II, III ( $\mathrm{III}_{\mathrm{I}}$ and $\mathrm{III}_{\mathrm{II}}$ ), and IV [4]. Cellulose I (CI) is the native material found in plants and consists of parallel polymer chains within crystallites and represented the unmodified cellulose. The remaining polymorphs are types of modified 
UNDERGRADUATE RESEARCH IN NATURAL AND CLINICAL SCIENCE AND TECHNOLOGY (URNCST) JOURNAL Read more URNCST Journal articles and submit your own today at: https://www.urncst.com

cellulose. Cellulose II (CII) can be formed either through alkaline treatment of any of the cellulose polymorphs and through regeneration of dissolved cellulose. Ammoniacal treatment of cellulose I and II yields cellulose III (CIII $)$ and cellulose IV (CIII ${ }_{\text {II }}$ [5] and these allomorphs can be converted into $\mathrm{CIV}_{\mathrm{I}}$ and $\mathrm{CIV}_{\mathrm{II}}$, respectively [6]. As shown in Figure 2 , the crystallinity of cellulose can be described in terms of crystalline and non-crystalline domains arranged as in a two-phase model, where crystalline and amorphous regions alternate $[7,8]$.

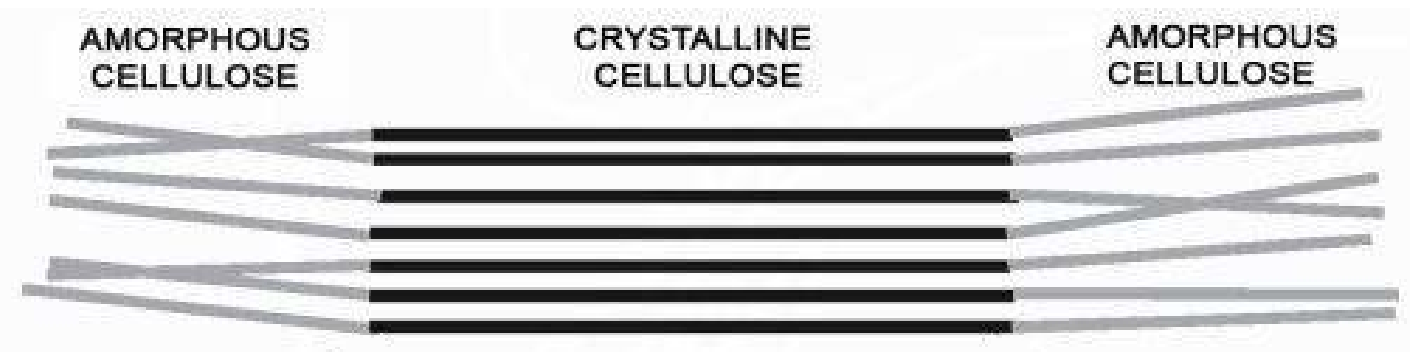

Figure 2. Two-phase model of cellulose; adapted from Quiroz Castañeda and Folch-Mallol [8].

The abundancy of cellulose crystalline regions will determine a material's properties [9]. For instance, for a higher DC hardness and stiffness (Young's modulus) increase, while flexibility decreases. Thus, degree of crystallinity is used to describe crystalline structures and influences the material's stiffness, hardness, and heat resistance [10].

Cellulose can be acquired from a variety of sources including plants, algae, bacteria, and tunicates. However, different organisms produce cellulose of various levels of DC which leads to drastically different mechanical properties and application possibilities. For example, as amorphous cellulose successfully prevents adhesion, it is effectively used as antioil-fouling material for water oil separation [11], while MCC is applied in bio-composites, owing to its chemical inactivity and hygroscopicity [12]. Because of this, finding cheaper and more efficient ways to produce cellulose would have the potential of lowering the cost of such bio-composites. $\underline{\text { Sources of cellulose }}$

A wide variety of plant sources can be used for cellulose extraction, with the most important being wood and cotton; however, corn, banana, rice, aloe vera, and many others can serve the same purpose [3]. Properties and structure of cellulose from plant sources depend on different parameters including climate conditions, soil type and characteristics, botanical origin amongst others. On an industrial level, it is a low-cost, high-volume, sustainable option, with a relatively simple method of extraction, but for non-industrial conditions, other sources of MCC may be easier to synthesize - the process of extracting cellulose from plant sources is complex and involves several steps suitable only for large-scale industrial operations such as physical breakdown of the plant matter using processes such as grinding and homogenization [13] (Figure 3).

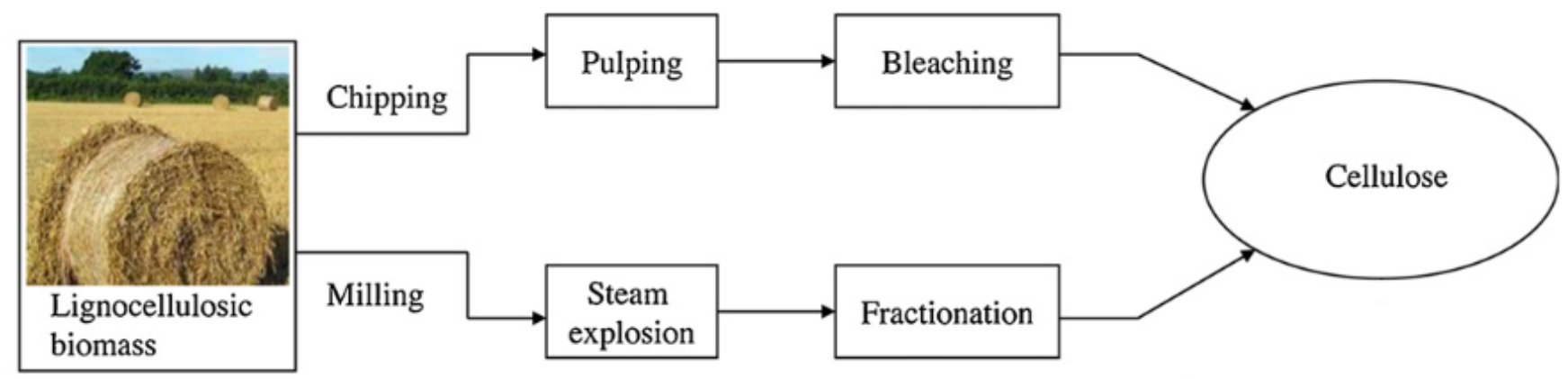

Figure 3. Industrial extraction of cellulose; adapted from Brinchi et al. [13].

Cellulose is also formed as a primary metabolic product of many bacteria, including Acetobacter xylinum and members of the Gluconacetobacter, Sarcina, and Agrobacterium genera [4]. Such cellulose is generally purer than that found in plants, does not contain lignin or hemicellulose, but rather only glucose monomers, and is formed in thin layers [14]. It is of the CI crystalline type and has a degree of polymerization (DP) between 2000 and 6000 [4]. DP in plant cellulose ranges from about 925 to 5500 and in algae it was shown to be 4300 [15]. DP has a direct impact 
on cellulose application-higher values result in a tougher final paper product. Bacteria found in a symbiotic culture of bacteria and yeast (SCOBY), as seen in Figure 4, used for production of beverages as kombucha and kimchi are known for their ability to grow a cellulose layer over the medium they inhabit $[16,17]$.

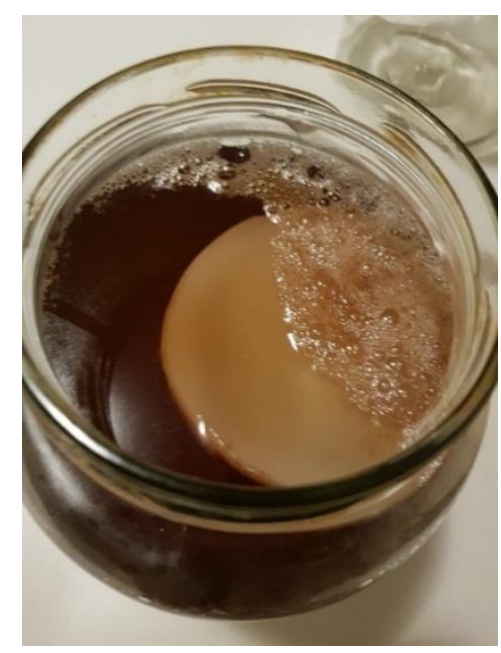

Figure 4. SCOBY floating on kombucha it was used to ferment.

Algal cellulose also does not always contain lignin and, therefore, has an even higher degree of crystallinity than bacterial cellulose [18]. Extracting algal cellulose is a means of remediation of marine ecosystems, as excessive and unwanted booking of algae damages the marine ecosystem. The extraction of microcrystalline cellulose is relatively simple and involves three groups of algae [3]. The first group, green algae (Chlorophyta), contain "native cellulose" and include species from the genera Cladophorales and Siphonocladales. Spongomorpha, which is a member of the second group, has "mercerized-like cellulose" with polymer chains randomly oriented resulting in a low DC. Cell walls found in the members of the third group (Spyrogira) are not entirely made up of cellulose [3]. Using X-ray diffractometry, marine green algae cellulose was found to be more crystalline, compared to that extracted from freshwater algae [19]. Cellulose nanofiber yield and physical properties depends on the season-algae harvested too early (with underdeveloped cell walls) or towards the end of the season were observed to have low tensile strength [18], compared to the optimal samples gathered midseason [20].

Tunicates are the only known animal source of cellulose [21]. Cellulose nanofibers (CNFs) can be extracted from the cover layer located over the entire epidermis, where cellulose-protein fibrils are cemented by sulfated mucopolysaccharides or sulfated glycans or lipids. However, given that tunicates are not widely available, other sources of cellulose may be preferable for applications.

Pesic | URNCST Journal (2021): Volume 5, Issue 2

DOI Link: https://doi.org/10.26685/urncst.200
Porosity

Porosity is an important morphological parameter in cellulose application. Pore shape, volume, and size distribution are all features of porous media [22] and can be modified by chemical and mechanical treatments. In bacterial cellulose, carbon sources can affect cellulose production as metabolic pathways may be longer for nonoptimal carbon sources, and, thus, pore size can vary [23]. Longer cultivation time decreases porosity due to a higher density of fibrils.

Pore size is important in the application of cellulose as it determines a material's water-holding capacity and oxygen permeability. This is a significant aspect of cellulose which makes it a fascinating candidate for applications that require films of controllable porosity, such as mask filters. The question that stems from the abundance of cellulose and a myriad of extraction methods; is it possible to grow cellulose of controllable porosity feasibly using unconventional production methods?

\section{Methods}

Extraction of cellulose from plants and algae

Before the process of extraction, to prepare for the chemical treatment, raw materials are milled or ground and purified [3].

\section{$\underline{\text { Plant cellulose }}$}

The first step of the extraction of cellulose from plants involves removing other compounds and components, including oils, wax, pectin, lignin, and hemicellulose [3]. A method described by Samiee et al. [3] involves alkalibleaching for purification and a treatment with $\mathrm{NaClO}_{2}$ solution under acidic conditions. In the main step, amorphous regions of cellulose are removed by acid hydrolysis, with either $\mathrm{HCl}$ or $\mathrm{H}_{2} \mathrm{SO}_{4}$, which does not impact stronger and more resistant crystalline regions. The same process hydrolyzes the remaining hemicellulose and pectin, yielding simple sugars.

\section{Algal cellulose}

Since cellulose derived from algae and plants is similar both chemically and structurally, Samiee et al. [3] indicate that the extraction processes are similar. However, since many species of algae contain colorful pigments, the extraction process may need additional steps for pigment removal, where $\mathrm{NaClO}_{2}$ or $\mathrm{H}_{2} \mathrm{O}_{2}$ are used as bleaching agents.

Tarchoun et al. [24] described a method for the extraction of cellulose from the Posidonia oceania brown algae, involving initial extraction with ethanol, oven drying, treatment with hot water, acidification with sodium chlorite, and a treatment with potassium hydroxide for the removal of pectin and hemicellulose. The change of color from brown to white indicates the absence of lignin, which may not be present in all algae. After treatments, samples are washed with distilled water and the extracted cellulose is left to dry 
in order to prevent "self-destruction" of the material [3]. Then, mechanical treatments for controlling porosity are performed.

Koyama et al. [19] described a single method for the extraction of cellulose from various algae (Valonia, Cladophora, Micrasterias, Spirogyra, etc.) involving an alkaline treatment and acid hydrolysis, and a bleaching process similar to that described by Samiee et al. [3]. For non-industrial conditions, such method may be used, with the change in the bleaching process: $\mathrm{NaClO}_{2}$ may be replaced by the easily obtainable $\mathrm{H}_{2} \mathrm{O}_{2}$.

After extraction, algal cellulose is dried to prevent "selfdestruction" of the components [3].

\section{$\underline{\text { Bacterial cellulose }}$}

Members of the Gluconacetobacter genus found in a SCOBY are capable of growing cellulose. According to Ashjaran et al. [17], the optimal source of carbon for these species is glycerol. However, sucrose, glucose, or another source of carbon may be used to insure a different pace of cellulose production and ultimately, different porosity levels. The growth medium is kept inside a large container and water, bags of green or black tea are added, along with vinegar, necessary for cellulose production in these bacteria. After 2-3 weeks of incubation, an impure cellulose layer containing cells and medium residue is formed [17]. Tang et al. [23] showed that Gluconacetobacter xylinum produced a higher yield with lower porosity after longer incubation. For purification, deionized water and $80 \% \mathrm{NaOH}$ are used and neutralization by $1 \%$ acetic acid is performed afterwards. This results in a thin cellulose layer ready for post-extraction treatments.

\section{Post-growth Treatments}

In order to vary porosity levels, newly synthesized and purified cellulose can be dried using different methods which cause water within cellulose pores to evaporate due to capillary forces and high surface tension of water. The collapsing pressure, causing pores to shrink, is inversely proportional to the tube diameter [25]. Additionally, larger pore size affects internal liquid's pressure by increasing forces necessary for pore shrinkage, just as different temperature levels affect the way water leaves cellulose pores and, thus, the shrinkage of pores themselves. Park et al. [22] showed that water bound content drops as temperature increases. Some methods of drying more suitable for industrial use include freeze drying, drum drying, and spray drying [3]. However, there are methods that can be applied in non-laboratory conditions. Tang et al. [23] showed that freeze-drying resulted in significantly higher porosity compared to hot-air dried samples. Similar results may be replicated in home conditions by drying using accessible means: sunlight, keeping samples at room temperature or in a freezer for extended periods.

\section{Results}

Plant cellulose

The choice of a source of cellulose can be made based on the intended end-product. For instance, cellulose derived from banana peel is biodegradable and exhibits high crystallinity, while that extracted from Eucalyptus pulp has high retention value, strength, and high moduli of rupture and elasticity. Prakash Menon et al. [18] described various plant sources of cellulose nanofibers and properties of the fibers extracted from them including the sizes as illustrated in Table 1. It is interesting to note that a variety of different methods can be used to vary the size between a wide range of $2-260 \mathrm{~nm}$.

Table 1. Sources of cellulose, methods of preparation, and properties of the material; adapted from Prakash Menon et al. (18)

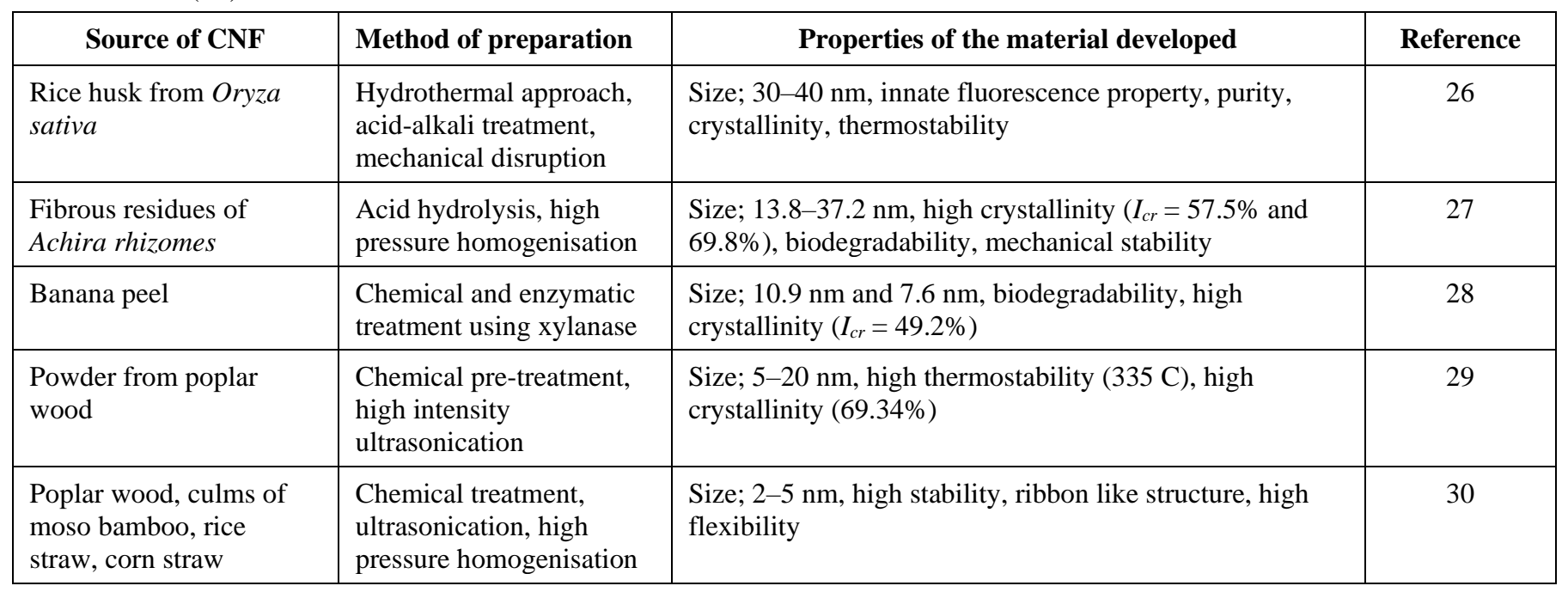


UNDERGRADUATE RESEARCH IN NATURAL AND CLINICAL SCIENCE AND TECHNOLOGY (URNCST) JOURNAL Read more URNCST Journal articles and submit your own today at: https://www.urncst.com

\begin{tabular}{|c|c|c|c|}
\hline Source of CNF & Method of preparation & Properties of the material developed & Reference \\
\hline $\begin{array}{l}\text { Posidonia oceanica balls } \\
\text { and leaves }\end{array}$ & $\begin{array}{l}\text { Chemical treatment, } \\
\text { fibrillation }\end{array}$ & Size; $5-21 \mathrm{~nm}$ and $2-15 \mathrm{~nm}$ & 32 \\
\hline $\begin{array}{l}\text { Waste pulp residues from } \\
\text { paper industry }\end{array}$ & $\begin{array}{l}\text { Etherification of pulp, } \\
\text { mechanical disintegration }\end{array}$ & $\begin{array}{l}\text { Size; } 10-100 \mathrm{~nm} \text {, high fibrillation, high thermostability } \\
\left(320^{\circ} \mathrm{C}\right) \text {, high nitrate adsorption capacity }\left(0.7 \mathrm{mmol} \mathrm{g}^{-1}\right)\end{array}$ & 34 \\
\hline Culinary banana peel & $\begin{array}{l}\text { Chemical treatment, high } \\
\text { intensity ultrasonication }\end{array}$ & $\begin{array}{l}\text { High crystallinity }\left(I_{c r}=63.64 \%\right) \text {, high thermal stability } \\
\left(295.33^{\circ} \mathrm{C}\right)\end{array}$ & 35 \\
\hline Canola straw & Nanowelding & $\begin{array}{l}\text { Size; } 53 \pm 16 \mathrm{~nm} \text {, high tensile strength }(208 \mathrm{MPa}) \text {, } \\
\text { Young's modulus }(20 \mathrm{GPa}) \text {, superior transparency }(76 \%) \text {, } \\
\text { biodegradability }\end{array}$ & 37 \\
\hline $\begin{array}{l}\text { Oil palm trunk, oil palm } \\
\text { frond, okara }\end{array}$ & $\begin{array}{l}\text { Alkaline treatment, } \\
\text { electrospinning }\end{array}$ & $\begin{array}{l}\text { Size; }<500 \mathrm{~nm} \text {, high fiber content }(107.9 \%, 67.2 \% \text {, } \\
25.1 \%) \text {, high anti-oxidant activity }(377.2 \%, 367.8 \%) \text {, } \\
\text { superior mineral }(\mathrm{Fe}, \mathrm{Zn}, \mathrm{Cu}, \mathrm{Ca}) \text { binding activity, high } \\
\text { emulsion activity }(66.3 \pm 0.6 \%, 6.6 \pm 0.1 \%, 4.0 \pm 0.1 \%)\end{array}$ & 38 \\
\hline
\end{tabular}

\section{$\underline{\text { Algal cellulose }}$}

While algal cellulose is structurally similar to plant cellulose, the extraction process is generally simpler and cheaper, especially as algae that do not have lignin in their fiber result in a higher quality final product [3]. Algal cellulose also exhibits a higher rate of growth compared to plants which gives them an advantage in industrial applications. Algal cellulose can grow in a wider range of conditions such as oceans, lakes, ponds, and wastewaters [3]. Koyama et al. [19] used a single method for the extraction of cellulose from various algae (Valonia, Cladophora, Micrasterias, Spirogyra, etc.) involving an alkaline treatment and acid hydrolysis, and a bleaching process similar to the one used in the extraction of cellulose from plant sources. For non-industrial, conditions such methods may be used, with a modified bleaching process $-\mathrm{NaClO}_{2}$ may be replaced with the easily obtainable $\mathrm{H}_{2} \mathrm{O}_{2}$. Also, for ease of extraction, algae with no lignin should be chosen, in which case a step can be skipped.

\section{Bacterial cellulose}

Cellulose layers formed over media containing SCOBYs will have different properties based on the cultivation conditions [17]. Longer cultivation time decreases porosity due to a higher density of fibrils produced. Therefore, cultivation time and type of carbon source used form critical parameters that can be tuned for a controllable porosity. As for other sources of cellulose, post- growth mechanical treatments are required for this control over porosity.

\section{Discussion}

Plant cellulose

Different end-product properties of plant-derived cellulose allow for a variety of applications: food-packaging, cationic and anionic electrodes, and as drug carrying vehicles for scaffold substrate in tissue engineering [39]. However, methods for extraction are complex and are often adapted for industrial or laboratory conditions, while other types of cellulose may be adapted for the same purposes. Additionally, conventional hydrolysis treatments are not considered environment-friendly, unlike other industrial processes such as enzymatic hydrolysis [3]. As a candidate for a small-scale production, plant cellulose is perhaps not the best candidate and algae and bacteria may be preferable sources of cellulose.

\section{$\underline{\text { Algal cellulose }}$}

Due to their strength, CNFs extracted from Cladophora have a good potential for applications [21] such as food packaging, wound dressings, and pharmaceutical applications such as hydrogels. They can also be used for the fabrication of conductive paper-based energy storage devices [40]. Here, nanocellulose fibers would serve as the porous interlayer and flexible substrate for lithium metal batteries [41]. 
However, despite both high crystallinity and advantageous properties of algal CNFs, growing bacterial cellulose at a small scale may still be preferable for applications as it has greater reproducibility and more room for tuning of parameters for favorable properties. Figure 5 demonstrates differences in structures between the three sources of cellulose-bacterial microcrystalline fibrils are smaller than algal and plant ones (around 100 times) [42].

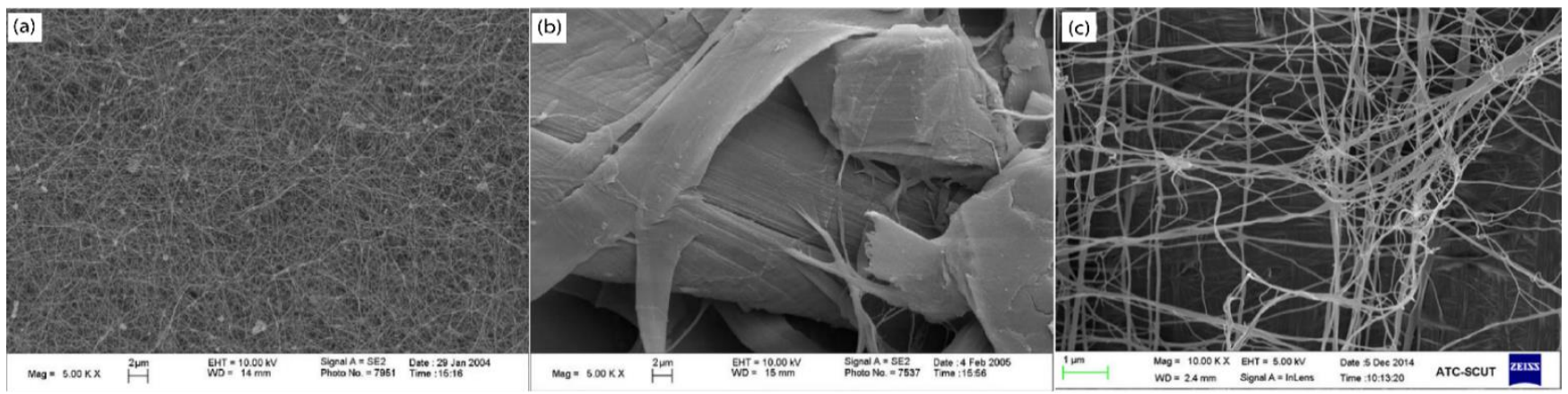

Figure 5. Scanning electron microscope images of (a) bacterial cellulose, (b) wood pulp (middle), and (c) algae cellulose; adapted from Czaja et al. [39] and Xiang et al. [42].

\section{Bacterial cellulose}

Growing bacterial cellulose at home and on a small scale is certainly possible and can be adjusted for varying porosity levels. In fact, cellulose is the main component of a fermented coconut water gel, 'Nata de Coco' [43]. Similar methods in controlled laboratory conditions are still preferable and more efficient. A single, pure bacterial culture can be grown under sterile and more controlled conditions. And the biggest challenge is the isolation of the desirable cellulose producing strain of bacteria from others that may reduce the quality of cellulose produced or in some cases, bacteria that produce toxins. However, since growing cellulose using SCOBY bacteria requires easily obtainable ingredients and no expensive equipment, it gives an opportunity to individuals to produce substantial amounts of cellulosic material where such may not be easily obtainable.

The COVID-19 pandemic has raised demand for face masks and various materials are used for their production. Pure cellulose can be used for this purpose [44], and the ability to grow cellulose layers at non-industrial/home conditions would provide an accessible alternative to commercial masks. Maximum protection is achieved by adjusting porosity during bacterial incubation and after growth. Another advantage of pure cellulose face masks is that they are often more biodegradable compared to the commercial alternatives.

Other uses of bacterial cellulose include skin transplantation - both in the case of donors and acceptors and was proven to be capable of substituting the dura mater in the dog brain [44]. In fact, bacterial cellulose has been used in a variety of medical applications from hydrogel bandages [45] to drug delivery [46]. Out of all the various sources of cellulose, bacterial cellulose allows for the easiest controllable processing of cellulose and has a high enough degree of crystallinity. Cellulose pore size determines a material's waterholding capacity and oxygen permeability and is important in tissue engineering. Artificial skin made from cellulose allows antibiotics and medication to enter wounds, while preventing outside pathogens from entering the host's body [47].

\section{Conclusions}

The study outlines differences between cellulose fibers derived from various sources, their properties, and advantages and disadvantages of each source. Overall, bacterial cultures are believed to be the most optimal one for home growth - all the required materials are widely available, and cultivation conditions can be altered for the intended end-product. After cultivation, porosity can be tuned by mechanical treatments, and the variety of final products allows for vast application: from face masks (smaller pores) to sustainable lithium batteries (larger pores). Further research is needed for improving culturing conditions and mechanical treatments for varying porosity. Also, simpler extraction processes should be explored for other sources of cellulose.

\section{List of Abbreviations}

MCC: microcrystalline cellulose

DC: degree of crystallinity

CI: cellulose I

CII: cellulose II

CIII: cellulose $\mathrm{III}_{\mathrm{I}}$

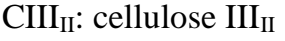

$\mathrm{CIV}_{\mathrm{I}}$ : cellulose $\mathrm{IV}_{\mathrm{I}}$

$\mathrm{CIV}_{\mathrm{II}}$ : cellulose $\mathrm{IV}_{\mathrm{II}}$

SCOBY: symbiotic culture of bacteria and yeast

CNFs: cellulose nanofibers

\section{Conflicts of Interest}

The author declares that they have no conflict of interests. 
UNDERGRADUATE RESEARCH IN NATURAL AND CLINICAL SCIENCE AND TECHNOLOGY (URNCST) JOURNAL Read more URNCST Journal articles and submit your own today at: https://www.urncst.com

\section{Ethics Approval and/or Participant Consent}

As a literature review, the study did not require ethics approval or participant consent.

\section{Author's Contributions}

DP: contributed to the design of the study, the review of literature and collection of data, interpretation and analysis of the data, revised the manuscript, and gave final approval of the version to be published.

\section{Acknowledgements}

Ramis Arbi: was a mentor to the author-assisted in designing the study, literature search, data interpretation, and provided suggestions and comments regarding the article content.

Ayomide Fakuade: assisted with the structure of the study. Bi-ru Amy Yeung: reviewed the article and provided feedback on how to improve it.

\section{Funding}

This study was not funded.

\section{References}

[1] Nunes RCR. Rubber nanocomposites with nanocellulose. Progress in Rubber Nanocomposites [Internet]. Elsevier. 2017 [cited 2020 Aug 18]; p. 463-94. https://doi.org/10.1016/B978-0-08-100409-8.00013-9

[2] Haque A. A potential cellulose microfibril swelling enzyme isolated from Bacillus sp. AY8 enhances cellulose hydrolysis. Elsevier. 2015; 9. https://doi.org/ 10.1016/j.procbio.2015.02.003

[3] Samiee S, Ahmadzadeh H, Hosseini M, Lyon S. Algae as a Source of Microcrystalline Cellulose. Advanced Bioprocessing for Alternative Fuels, Biobased Chemicals, and Bioproducts [Internet]. Elsevier. 2019 [cited 2020 Aug 18]; p. 331-50. https://doi.org/10.1016/ B978-0-12-817941-3.00017-6

[4] Kargarzadeh H, Ioelovich M, Ahmad I, Thomas S, Dufresne A. Methods for Extraction of Nanocellulose from Various Sources. In: Kargarzadeh H, Ahmad I, Thomas S, Dufresne A, editors. Handbook of Nanocellulose and Cellulose Nanocomposites [Internet]. Weinheim, Germany: Wiley-VCH Verlag GmbH \& Co. KGaA. 2017 [cited 2020 Aug 18]; p. 1-49. http://doi.wiley.com/10.1002/9783527689972.ch1

[5] Kaplan RA, Pak CYC. Effect of Sodium Cellulose Phosphate Therapy on Crystallization of Calcium Oxalate in Urine. Metabolism. 1975; 24(11):1273-1278. https://doi.org/10.1016/0026-0495(75)90065-7

[6] Gardiner ES, Sarko A. Packing analysis of carbohydrates and polysaccharides. The crystal structures of celluloses IVI and IVII. Canadian Science Publishing. 1985; 8. https://doi.org/10.1139/v85-027

[7] Garvey CJ, Parker IH, Simon GP. On the Interpretation of X-Ray Diffraction Powder Patterns in Terms of the Nanostructure of Cellulose I Fibres. Macromol Chem
Phys. 2005; 206(15):1568-75. https://doi.org/10.1002/ macp. 200500008

[8] Quiroz Castañeda R, Folch-Mallol J. Degradation of Lignocellulosic Biomass - Techniques, Applications and Commercialization Sustainable Degradation of Lignocellulosic Biomass - Techniques, Applications and Commercialization. In 2013. p. 275.

[9] Andersson S, Serimaa R, Paakkari T, Saranp ̈̈̈ P, Pesonen E. Crystallinity of wood and the size of cellulose crystallites in Norway spruce (Picea abies). J Wood Sci. 2003; 49(6):531-7. https://doi.org/10.1007/ s10086-003-0518-X

[10]Crompton TR. Degree of Crystallinity and Melting Temperature. Practical Polymer Analysis. Boston, MA: Springer US. 1993; p. 630-47. Available from: https://doi.org/10.1007/978-1-4615-2874-6_13

[11] Zhou X, Koh JJ, He C. Robust Oil-Fouling Resistance of Amorphous Cellulose Surface Underwater: A Wetting Study and Application. Langmuir. 2019; 35(4):839-47. https://doi.org/10.1021/acs.langmuir.8b03560

[12] Trache D, Hussin MH, Hui Chuin CT, Sabar S, Fazita MRN, Taiwo OFA, Hassan TM, Haafiz MKM. Microcrystalline cellulose: Isolation, characterization and bio-composites application-A review. International Journal of Biological Macromolecules. 2016; 93:789804. https://doi.org/10.1016/j.ijbiomac.2016.09.056

[13] Brinchi L, Cotana F, Fortunati E, Kenny JM. Production of nanocrystalline cellulose from lignocellulosic biomass: Technology and applications. Carbohydrate Polymers. 2013; 94(1):154-69. $\quad$ https://doi.org/10.1016/ j.carbpol.2013.01.033

[14] Esa F, Tasirin SM, Rahman NA. Overview of Bacterial Cellulose Production and Application. Agriculture and Agricultural Science Procedia. 2014; 2:113-9. https://doi.org/10.1016/j.aaspro.2014.11.017

[15] Hallac BB, Ragauskas AJ. Analyzing cellulose degree of polymerization and its relevancy to cellulosic ethanol. Biofuels, Bioprod Bioref. 2011; 5(2):215-25. https://doi.org/10.1002/bbb.269

[16] Marsh AJ. Sequence-based analysis of the bacterial and fungal compositions of multiple kombucha (tea fungus) samples. Food Microbiology. 2014; 8. https://doi.org/ 10.1016/j.fm.2013.09.003

[17] Ashjaran A, Yazdanshenas ME, Rashidi A, Khajavi R, Rezaee A. Overview of bio nanofabric from bacterial cellulose. Journal of The Textile Institute. 2013; 104(2):121-31. https://doi.org/10.1080/00405000.2012 .703796

[18] Prakash Menon M, Selvakumar R, Suresh kumar P, Ramakrishna S. Extraction and modification of cellulose nanofibers derived from biomass for environmental application. RSC Adv. 2017; 7(68):42750-73. https://doi.org/10.1039/C7RA06713E

[19] Koyama M, Sugiyama J, Itoh T. Systematic survey on crystalline features of algal celluloses. Cellulose 4. 1997; 147-160. https://doi.org/10.1023/A:1018427604670 
UNDERGRADUATE RESEARCH IN NATURAL AND CLINICAL SCIENCE AND TECHNOLOGY (URNCST) JOURNAL

Read more URNCST Journal articles and submit your own today at: https://www.urncst.com

[20] Johnson M, Shivkumar S, Berlowitz-Tarrant L. Structure and properties of filamentous green algae. Materials Science and Engineering B. 1996; 38(1-2):103-108. https://doi.org/10.1016/0921-5107(95)01315-6

[21] Zhao Y, Moser C, Lindström ME, Henriksson G, Li J. Cellulose Nanofibers from Softwood, Hardwood, and Tunicate: Preparation-Structure-Film Performance Interrelation. ACS Appl Mater Interfaces. 2017; 9(15):13508-19. https://doi.org/10.1021/acsami.7b01738

[22] Park S, Venditti R, Jameel H, Pawlak J. Changes in pore size distribution during the drying of cellulose fibers as measured by differential scanning calorimetry. Carbohydrate Polymers. 2006; 66(1):97-103. Available from: https://doi.org/10.1016/j.carbpol.2006.02.026

[23] Tang W, Jia S, Jia Y, Yang H. The influence of fermentation conditions and post-treatment methods on porosity of bacterial cellulose membrane. World J Microbiol Biotechnology. 2010; 26(1):125-31. https://doi.org/10.1007/s11274-009-0151-y

[24] Tarchoun AF, Trache D, Klapötke TM. Microcrystalline cellulose from Posidonia oceanica brown algae: Extraction and characterization. International Journal of Biological Macromolecules. 2019 Oct;138:837-45. https://doi.org/https://doi.org/10.1016/j.ijbiomac.2019.07. $\underline{176}$

[25] Marks LS. Marks' standard handbook for mechanical engineers. Eleventh editon, [90. anniversary edition]. Avallone EA, Baumeister T, Sadegh AM, editors. New York: McGraw-Hill; 2007.

[26] Kalita E, Nath BK, Deb P, Agan F, Islam RMd, Saikia K. High quality fluorescent cellulose nanofibers from endemic rice husk: isolation and characterization. Carbohydrate Polymers. 2015; 122:308-313. https://doi.org/10.1016/j.carbpol.2014.12.075

[27] Andrade-Mahecha MM, Pelissari FM, Tapia-Bl'acido DR, Menegalli FC. Achira as a source of biodegradable materials: Isolation and characterization of nanofibers. Carbohydrate Polymers. 2015; 123:406-415. https://doi.org/10.1016/j.carbpol.2015.01.027

[28] Tibolla H, Pelissari FM, Menegalli FC. Cellulose nanofibers produced from banana peel by chemical and enzymatic treatment. LWT-Food Sci. Technol. 2014; 59:1311-1318. https://doi.org/10.1016/j.lwt.2014.04.011

[29]Chen W, Yu H, Liu Y, Hai Y, Zhang M, Chen P. Isolation and characterization of cellulose nanofibers from four plant cellulose fibers using a chemicalultrasonic process. Cellulose. 2011; 18(2):433-42. https://doi.org/10.1007/s10570-011-9497-z

[30] Sun L, Chen W, Liu Y, Li J, Yu H. Soy protein isolate/cellulose nanofiber complex gels as fat substitutes: rheological and textural properties and extent of cream imitation. Cellulose. 2015; 22(4):2619-27. https://doi.org/10.1007/s10570-015-0681-4

[31] Jiang F, Hsieh Y-L. Cellulose nanocrystal isolation from tomato peels and assembled nanofibers. Carbohydrate
Polymers. 2015; 122:60-8. https://doi.org/10.1016/ j.carbpol.2014.12.064

[32] Bettaieb F, Nechyporchuk O, Khiari R, Mhenni MF, Dufresne A, Belgacem MN. Effect of the oxidation treatment on the production of cellulose nanofiber suspensions from Posidonia oceanica: The rheological aspect. Carbohydrate Polymers. 2015; 134:664-72. https://doi.org/10.1016/j.carbpol.2015.07.091

[33] Soni B, Hassan EB, Mahmoud B. Chemical isolation and characterization of different cellulose nanofibers from cotton stalks. Carbohydrate Polymers. 2015; 134:581-9. https://doi.org/10.1016/j.carbpol.2015.08.031

[34] Sehaqui H, Mautner A, Perez de Larraya U, Pfenninger $\mathrm{N}$, Tingaut $\mathrm{P}$, Zimmermann $\mathrm{T}$. Cationic cellulose nanofibers from waste pulp residues and their nitrate, fluoride, sulphate and phosphate adsorption properties. Carbohydrate Polymers. 2016; 135:334-40. https://doi.org/10.1016/j.carbpol.2015.08.091

[35] Khawas P, Deka SC. Comparative Nutritional, Functional, Morphological, and Diffractogram Study on Culinary Banana (Musa ABB) Peel at Various Stages of Development. International Journal of Food Properties. 2016; 19(12):2832-53. https://doi.org/10.1080/ 10942912.2016 .1141296

[36] Theng D. All-lignocellulosic fiberboard from corn biomass and cellulose nanofibers. Industrial Crops and Products. 2015; 8:167-173. https://doi.org/10.1016/ j.indcrop.2015.06.046

[37] Yousefi H, Nishino T, Faezipour M, Ebrahimi G, Shakeri A. Direct Fabrication of all -Cellulose Nanocomposite from Cellulose Microfibers Using Ionic Liquid-Based Nanowelding. Biomacromolecules. 2011; 12(11):4080 5. https://doi.org/10.1021/bm201147a

[38] Cara C, Ruiz E, Ballesteros M, Manzanares P, Negro MJ, Castro E. Production of fuel ethanol from steam-explosion pretreated olive tree pruning. Fuel. 2008; 87(6): 692-700. https://doi.org/10.1016/j.fuel.2007.05.008

[39] Czaja W, Krystynowicz A, Bielecki S, Brown jr. R. Microbial cellulose - the natural power to heal wounds. Biomaterials. 2006; 27(2):145-51. https://doi.org/ 10.1016/j.biomaterials.2005.07.035

[40] Nyström G, Razaq A, Strømme M, Nyholm L, Mihranyan A. Ultrafast All-Polymer Paper-Based Batteries. Nano Lett. 2009; 9(10): 5. https://doi.org/ $\underline{10.1021 / \mathrm{n} 1901852 \mathrm{~h}}$

[41] Wang Z, Pan R, Sun R, Edström K, Strømme M, Nyholm L. Nanocellulose Structured Paper-Based Lithium Metal Batteries. ACS Applied Energy Materials. 2018; 1(8):4341-50. https://doi.org/10.1021/ acsaem.8b00961

[42] Xiang Z, Gao W, Chen L, Lan W, Zhu JY, Runge T. A comparison of cellulose nanofibrils produced from Cladophora glomerata algae and bleached eucalyptus pulp. Cellulose. 2016 Feb; 23(1):493-503. https://doi.org/10.1007/s10570-015-0840-7 
UNDERGRADUATE RESEARCH IN NATURAL AND CLINICAL SCIENCE AND TECHNOLOGY (URNCST) JOURNAL

Read more URNCST Journal articles and submit your own today at: https://www.urncst.com

[43] Budhiono A, Rosidi B, Taher H, Iguchi M. Kinetic aspects of bacterial cellulose formation in nata-de-coco culture system. Carbohydrate Polymers. 1999; 40(2):137-43. $\quad$ https://doi.org/10.1016/S0144-8617(99) 00050-8

[44] Sum studio's home-grown cellulose mask promotes the benefits of biodesign [Internet]. designboom | architecture $\&$ design magazine. [cited 2020 Oct 23]; Available from: https://www.designboom.com/design/ sum-studio-home-grown-cellulose-mask-biodesign-05$13-2020 /$

[45] Jonas R, Farah LF. Production and application of microbial cellulose. Polymer Degradation and Stability.
1998; 59(1-3):101-106. https://doi.org/10.1016/s01413910(97)00197-3

[46] Portela R, Leal CR, Almeida PL, Sobral RG. Bacterial cellulose: a versatile biopolymer for wound dressing applications. Microb Biotechnol. 2019; 12(4):586-610. https://doi.org/10.1111/1751-7915.13392

[47] Abeer MM, Mohd Amin MCI, Martin C. A review of bacterial cellulose-based drug delivery systems: their biochemistry, current approaches and future prospects: Review of BC-based drug delivery systems. J Pharm Pharmacol. 2014; 66:1047-1061. https://doi.org/10.1111/ jphp.12234

\section{Article Information}

Managing Editor: Jeremy Y. Ng

Peer Reviewers: Ramis Arbi, Bi-ru Amy Yeung

Article Dates: Received Nov 01 20; Accepted Dec 30 20; Published Feb 0321

\section{Citation}

Please cite this article as follows:

Pesic DB. Cellulose in nature - versatile sources for novel applications: A literature review. URNCST Journal. 2021 Feb 03:

5(2). https://urncst.com/index.php/urncst/article/view/200

DOI Link: https://doi.org/10.26685/urncst.200

\section{Copyright}

(C) Dusan B. Pesic. (2021). Published first in the Undergraduate Research in Natural and Clinical Science and Technology (URNCST) Journal. This is an open access article distributed under the terms of the Creative Commons Attribution License (https://creativecommons.org/licenses/by/4.0/), which permits unrestricted use, distribution, and reproduction in any medium, provided the original work, first published in the Undergraduate Research in Natural and Clinical Science and Technology (URNCST) Journal, is properly cited. The complete bibliographic information, a link to the original publication on http://www.urncst.com, as well as this copyright and license information must be included.
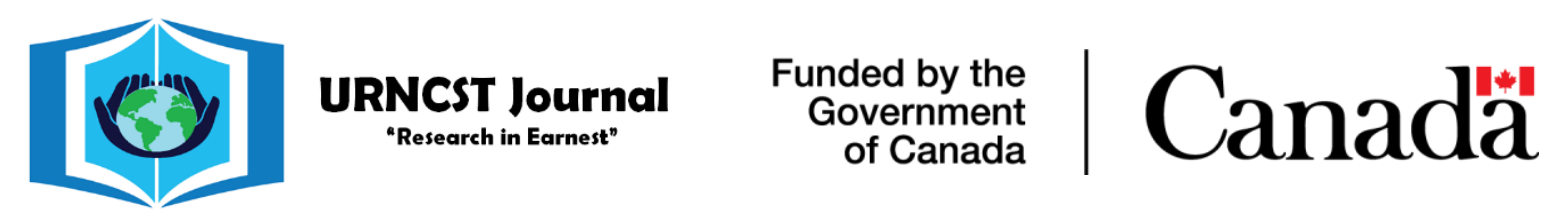

Do you research in earnest? Submit your next undergraduate research article to the URNCST Journal!

| Open Access | Peer-Reviewed | Rapid Turnaround Time | International |

| Broad and Multidisciplinary | Indexed | Innovative | Social Media Promoted |

Pre-submission inquiries? Send us an email at info@ urncst.com | Facebook, Twitter and LinkedIn: @URNCST

Submit YOUR manuscript today at https://www.urncst.com! 